3 Indu Singh

Andrew L. Carey

Nadine Watson

Mark A. Febbraio

John A. Hawley

\section{Oxidative stress-induced insulin resistance in skeletal muscle cells is ameliorated by gamma-tocopherol treatment}

Received: 29 June 2008

Accepted: 9 September 2008

Published online:

\section{Singh $\cdot$ A.L. Carey}

J.A. Hawley, PhD ( $\square)$

Exercise Metabolism Group

School of Medical Sciences

RMIT University, PO Box 71

Bundoora (VIC) 3083, Australia

E-Mail: john.hawley@rmit.edu.au

N. Watson - M.A. Febbraio

Cellular and Molecular Metabolism

Laboratory

Baker Heart Research Institute

Melbourne (VIC), Australia
Abstract Background Oxidative stress-induced reactive oxygen species are associated with the clinical manifestation of insulin resistance. Evidence suggests that antioxidant treatment may reduce this incidence. Aim of the study This study determined whether glucose oxidase (GO)-induced insulin resistance in cultured skeletal muscle cells could be ameliorated by pre-treatment with gamma-tocopherol (GT). Methods Insulin sensitivity in L6 myotubes was assessed by 2 deoxy-D- $\left[{ }^{3} \mathrm{H}\right]$-glucose uptake. The phosphorylation of distal insulin signaling proteins Akt and the Akt substrate AS160 were determined by western blot. Results One hour treatment with $100 \mathrm{mU} / \mathrm{ml} \mathrm{GO}$ decreased insulin-stimulated glu- cose uptake $(P<0.001)$. Pretreatment with GT either partially $(100 \mu \mathrm{M})$ or completely $(200 \mu \mathrm{M})$ restored insulin-stimulated glucose uptake in cells after GOinduced insulin resistance. GOinduced oxidative stress did not impair insulin stimulated phosphorylation of Akt or AS160, but $200 \mu \mathrm{M}$ GT increased insulinstimulated phosphorylation of these key signaling proteins $(P<0.05)$. Conclusions Highdose $(200 \mu \mathrm{M})$ GT treatment ameliorated oxidative stress-induced insulin resistance in cultured rat L6 skeletal muscle cells.

Key words glucose oxidase L6 myotubes - Akt AS160 - glucose transport antioxidants

\section{Introduction}

There is accumulating evidence that the generation of reactive oxygen species (ROS) leads to increased oxidative stress and is a precursor to a number of chronic conditions including type- 2 diabetes and cardiovascular disease [33]. Antioxidant agents have been proposed to arrest some of the deleterious effects of ROS $[1,17]$ either by donating hydrogen to free radicals or by accepting free radicals and therefore neutralizing their effect. Gamma-tocopherol (GT), an isoform of Vitamin E present in food has been shown to have potent antioxidant effects [33]. GT inhibits platelet aggregation to a greater extent than alpha-tocopherol, as platelets isolated from humans supplemented with a mixed-tocopherol preparation exhibited reduced aggregation after mixedtocopherol compared to alpha-tocopherol supplementation [20]. In addition, we have recently demonstrated that pure GT inhibited platelet aggregation and improved lipid profile in normal healthy subjects, thereby playing a potential role in prevention of thrombosis [28].

Type-2 diabetes is characterized by insulin resistance in various tissues; in particular, skeletal muscle,

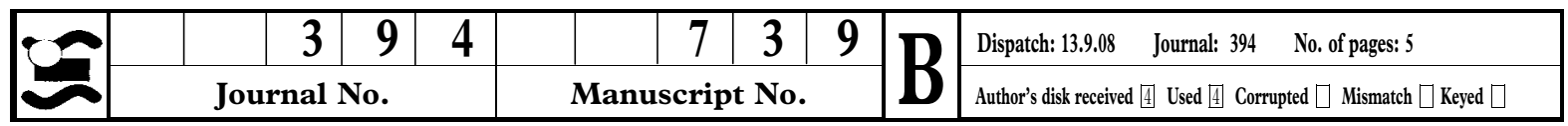


the primary site for insulin-stimulated glucose disposal [2]. While there is evidence that oxidative stress leads to insulin resistance $[6,17]$, tissue damage and pathogenesis of late diabetic complications [25], the exact mechanisms responsible remain unclear. In skeletal muscle cells, insulin-stimulated uptake of glucose depends on a number of signaling components, culminating in the translocation of vesicles containing the glucose transporter GLUT4 to the cell surface [16]. The effects of ROS on the insulin signaling cascade are equivocal $[10,13,14,26]$, but the results of several studies demonstrate that ROS impairs insulin-mediated glucose uptake and storage [4, $10,18,27,32]$, via disruption at signaling control points such as GSK-3b [4] Akt phosphorylation and/ or actin remodeling [14]. While it has been proposed that Vitamin E supplementation might prevent ROSinduced impairment of insulin signaling [7], and improve biomarkers of metabolic syndrome [3] studies of the effects of antioxidant treatment on insulin signaling and simultaneous functional measures of glucose transport are lacking. If ROS are involved in causing damage to cellular signaling machinery, antioxidant treatment may be able to alleviate or prevent such an occurrence. Accordingly, the primary purpose of the current investigation was to determine whether GT, which we have previously demonstrated to have potent antioxidant properties [28], could ameliorate the deleterious effects of oxidative stress on insulin sensitivity. In addition, we also investigated the effects of GT treatment on the most distal signaling protein identified in signaling to GLUT4 vesicles for insulin-stimulated translocation to the cell surface, the Akt substrate AS160.

\section{Materials and methods}

\section{Cell culture}

L6 skeletal myoblasts (American Type Cell Collection, VA, USA) were cultured using aseptic techniques in $75 \mathrm{~cm}^{2}$ flasks containing growth media, which consisted of DMEM supplemented with $10 \%$ FBS, $1 \%$ penicillin/streptomycin (v:v) at $37^{\circ} \mathrm{C}$ in $5 \% \quad \mathrm{CO}_{2} /$ $95 \% \mathrm{O}_{2}$ in humidified air. Media was replaced daily with pre-warmed media $\left(37^{\circ} \mathrm{C}\right)$ until the cells were $60-70 \%$ confluent. Cells were washed twice with prewarmed PBS then detached with $2 \mathrm{ml}$ of $0.25 \%$ trypsin for 3-4 min with intermittent shaking. Once the cells were completely detached the total number of cells were counted then seeded into six well plates at 7,000 cells per $\mathrm{cm}^{2}$. Cells were grown to $60-70 \%$ confluency in $\alpha$-modified essential medium $(\alpha \mathrm{MEM})+10 \%$ FBS before changing to differentiation media $(\alpha M E M+2 \%$ FBS) to allow myoblasts to differentiate into myotu- bes. Experimental treatments were conducted after 2 days, by which time nearly all of the myoblasts had fused to form myotubes. Cells were incubated with GT for $24 \mathrm{~h}$ (with concentrations indicated) and oxidative stress was induced by incubation by incubation with $100 \mathrm{mU} / \mathrm{ml}$ glucose oxidase (GO) during the final $1 \mathrm{~h}$ of this $24 \mathrm{~h}$ period. Similar doses and durations of GO treatment in skeletal myotubes or isolated skeletal muscle have been shown repeatedly to induce $>50$ fold increases in cellular $\mathrm{H}_{2} \mathrm{O}_{2}$ concentrations without affecting cell viability $[4,18,21,31]$.

\section{Glucose uptake}

For determination of 2-deoxy-D- $\left[{ }^{3} \mathrm{H}\right]$-glucose uptake, myotubes were incubated in $\alpha \mathrm{MEM}$ without glucose with $0.1 \%$ FBS for $4 \mathrm{~h}$. Cells were washed twice with warm PBS (containing $0.1 \%$ FBS) and equilibrated in $2 \mathrm{ml} \alpha \mathrm{MEM}$ (without glucose) for $30 \mathrm{~min}$ followed by incubation with or without $100 \mathrm{nM}$ insulin for $30 \mathrm{~min}$, before $800 \mu$ of radioactive media $(1 \mu \mathrm{Ci} / \mathrm{ml}$ 2-deoxy-D- $\left({ }^{3} \mathrm{H}\right)$-glucose, $10 \mu \mathrm{M}$ 2-deoxy-D-glucose in $\alpha \mathrm{MEM}, 0.1 \% \mathrm{FBS})$ was added to each well. After $30 \mathrm{~min}$ media was aspirated and the assay stopped by washing cells twice in ice-cold PBS. Cells were then lyzed in $1 \mathrm{ml}$ of $0.3 \mathrm{M} \mathrm{NaOH}$ and $800 \mu \mathrm{l}$ of the lysate in $4 \mathrm{ml}$ of scintillation fluid was counted via liquid scintillation.

\section{Western blotting}

L6 myotubes were grown, differentiated and treated as described under cell culture above. Lysis buffer [20 mM HEPES (pH 7.4), 2 mM EDTA, $50 \mathrm{mM} \mathrm{NaF}$, $5 \mathrm{mM} \mathrm{Na}_{4} \mathrm{P}_{2} \mathrm{O}_{7}, 1 \% \mathrm{NP} 40$ and phosphatase and protease inhibitor cocktails] was added and cells rapidly scraped then transferred to a $1.5 \mathrm{ml}$ tube and rapidly frozen in liquid nitrogen for later analysis. Subsequently, cell culture lysates were spun at $16,000 \mathrm{~g}$ for $5 \mathrm{~min}$, then $5 \mu \mathrm{l}$ of the supernatant taken and diluted 1:25 with water, before the protein concentration was determined using a commercially available kit (BCA ${ }^{\mathrm{TM}}$ Protein Assay Kit, Pierce, USA) using absorbance spectrophotometry. Absorbance of standards and samples was determined at $560 \mathrm{~nm}$ on a spectrophotometer and the protein content calculated from the linear regression.

Proteins solubilized in Lamelli's buffer $(\mathrm{pH} 6.8$ consisting of $40 \%$ glycerol, $8.2 \%$ sodium dodecyl sulfate (SDS), $0.5 \mathrm{M}$ Tris- $\mathrm{HCl}, 40 \mathrm{mM}$ dithiotrietol plus bromophenol blue) were added to $40 \mu \mathrm{g}$ of sample, heated for $5 \mathrm{~min}$ at $85^{\circ} \mathrm{C}$, and proteins resolved by SDS-PAGE using pre-cast polyacrylamide gradient gels and commercially available electrophoresis reagents (Invitrogen, VIC, Australia). A molec-

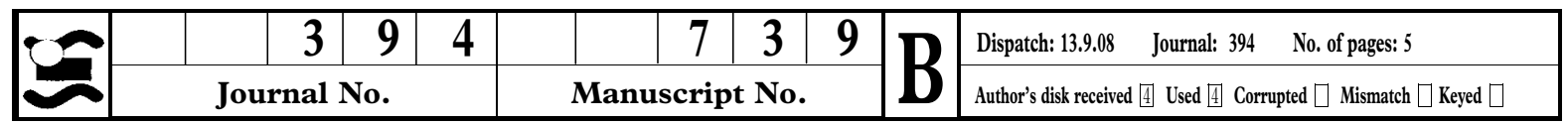


ular weight protein standard (Biorad, NSW, Australia), and solubilized protein samples were loaded into individual wells and run at $150 \mathrm{~V}$ until proteins had sufficiently migrated through the gel.

Separated proteins were then transferred to a PVDF membrane using pre-developed reagents and standard transfer sandwich apparatus (Invitrogen, VIC, Australia). Proteins were transferred at a constant voltage of $20 \mathrm{~V}$ for 100 (Akt) or 180 (AS160) min. After the transfer, the membrane was washed with Tris-buffered saline with Tween (TBST; $20 \mathrm{mM}$ Tris, $140 \mathrm{mM} \mathrm{NaCl}, 0.05 \%$ Tween 20, pH 7.6). The membrane was blocked with $5 \%$ skim milk powder $(\mathrm{w} / \mathrm{v})$ in TBST on a rocker at room temperature for $1 \mathrm{~h}$. After blocking, membranes were washed with TBST and incubated with primary antibodies (diluted $1: 1,000$ in TBST + $1 \%$ BSA) specific for phosphoAkt-Ser473, $\beta$-actin, Phospho-Akt-Substrate, total Akt (Cell Signaling Technology: Genesearch, QLD, Australia), phosphor-AMPK-Thr172 and total AMPK- $\alpha 1 /$ 2 (kind gifts from Prof Bruce Kemp) overnight on a rocker at $4^{\circ} \mathrm{C}$. Membranes were washed three times with TBST then incubated with secondary antibody (1:5,000 anti-rabbit antibodies in TBST) for $1 \mathrm{~h}$ at room temperature. The membrane was then washed $(6 \times 10 \mathrm{~min})$ with TBST and immunoreactive bands detected with $2 \mathrm{ml}$ of chemiluminescence reagent (Pierce: Quantum Scientific, QLD, Australia) and exposed using the Chemidoc EQ system (Biorad, NSW,
Australia). Proteins were quantified using Quantity One software version 9 (Biorad, NSW, Australia).

\section{Statistical analysis}

Data were analyzed using 2-way ANOVA, and $P$ values of $<0.05$ were considered significant. Results are presented as mean \pm SEM.

\section{Results}

Insulin treatment significantly increased glucose transport by $\sim 40 \%$ above vehicle $(P<0.001)$. One hour treatment with $100 \mathrm{mU} / \mathrm{ml} \mathrm{GO}$ significantly decreased insulin-stimulated glucose transport $(P<0.001)$, whereas pre-treatment with $100 \mu \mathrm{M}$ GT partially protected cells from the effect of GO, and $200 \mu \mathrm{M}$ GT restored $(P>0.05)$ insulin-stimulated glucose transport to similar levels as non-GO treated cells (Fig. 1).

To assess whether the protective effect of GT on basal and insulin-stimulated glucose transport after induction of oxidative stress was due to improved signaling from the insulin receptor to GLUT4 vesicles, the most distal of the well-characterized proteins in the insulin-GLUT4 signaling cascade were measured; we assessed the phosphorylation of Akt and AS160 on

Fig. 1 2-Deoxyglucose uptake in L6 myotubes that were differentiated as stated in "Materials and methods". Cells were treated with 100 or $200 \mu \mathrm{M}$ gamma-tocopherol (GT) for $24 \mathrm{~h}, 100 \mathrm{mU} / \mathrm{ml} \mathrm{GO}$ for $1 \mathrm{~h}$ and $100 \mathrm{nM}$ insulin for $30 \mathrm{~min}(n=8-$ 11). Asterisks significantly lower than treatment with insulin alone $(P<0.001)$

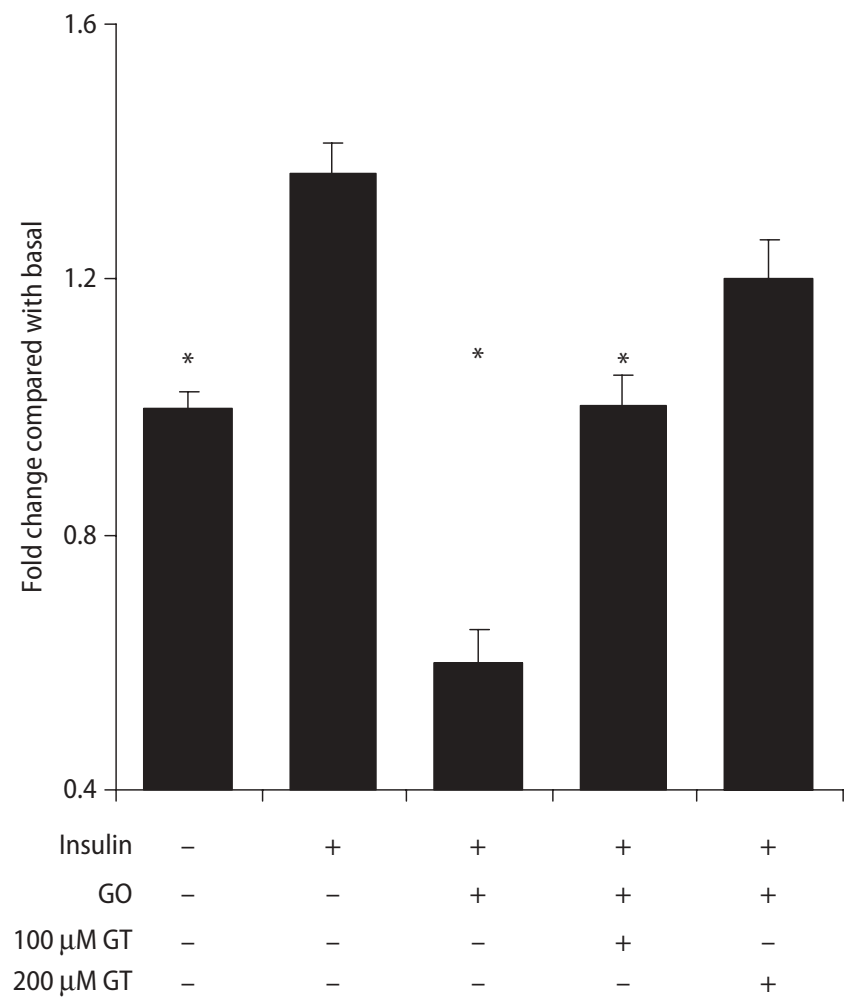

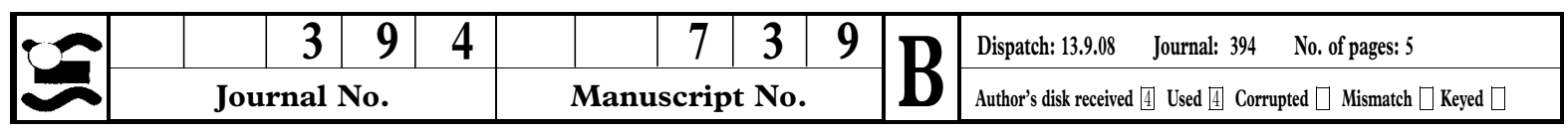



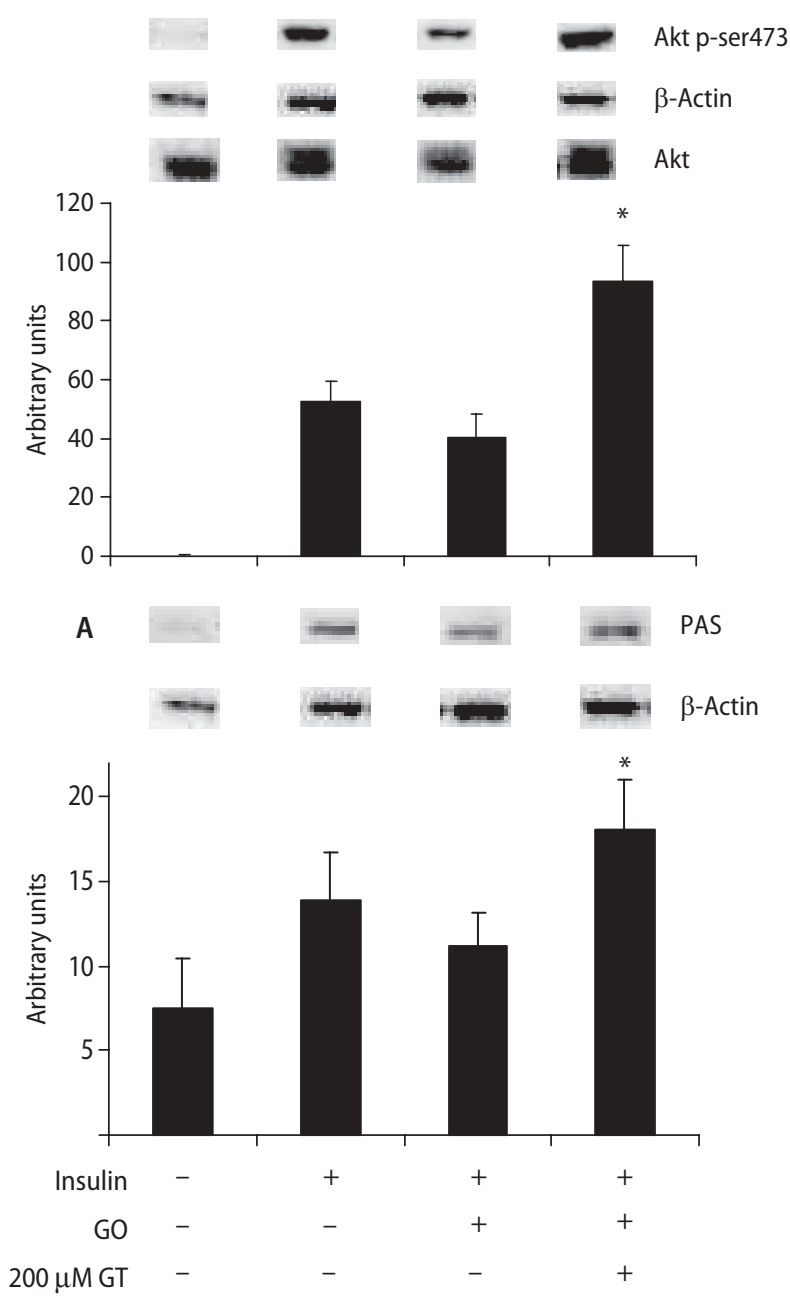

B

Fig. 2 Phosphorylation of Akt serine-473 (a) and AS160 (b) relative to total $\beta$ actin in $\mathbf{L 6}$ myotubes that were differentiated as described in "Materials and methods". Cells were treated with $200 \mu \mathrm{M}$ GT for $24 \mathrm{~h}, 100 \mathrm{mU} / \mathrm{ml} \mathrm{G0}$ for $1 \mathrm{~h}$ and $100 \mathrm{nM}$ insulin for $10 \mathrm{~min}(n=6)$. PAS phospho-Akt substrate. Asterisks significantly increased above all other conditions $(P<0.05)$ amino-acid residues that are important for insulin signaling to GLUT4. We found that GO did not impair insulin-stimulated phosphorylation of Akt or AS160, but $200 \mu \mathrm{M}$ GT increased insulin-stimulated phosphorylation of both $(P<0.05)$ above insulin treatment alone, and might partly explain the restoration of glucose transport in this condition (Fig. 2). In addition, since phosphorylation of neither Akt nor AS160 could completely explain the effects of GT on glucose transport, we measured phosphorylation of AMPK to determine whether activation of this stressactivated kinase could explain the changes seen. Phosphorylation of AMPK at Thr172, representative of an increase in activity [11] that would increase glucose transport [12], was not significantly altered by GT treatment (data not shown).

\section{Discussion}

In the present study we investigated the effects of GT on insulin-stimulated glucose transport and selected components of the insulin signaling cascade in cultured rat $\mathrm{L} 6$ myotubes exposed to $\mathrm{a}_{2} \mathrm{O}_{2}$ generating system. While GO treatment significantly reduced insulin-stimulated glucose transport, this reduction did not appear to be due to an impairment of insulin signaling, reflected by unaltered phosphorylations states of the distal insulin signaling proteins Akt and AS160. In contrast, treatment with $200 \mu \mathrm{M}$ GT ameliorated the GO-induced impairment in insulin-stimulated glucose transport and this coincided with significant increases in the insulin-stimulated phosphorylation of both Akt and AS160. Indeed, the phosphorylation states of these signaling proteins were greater after the high dose of GT than observed when treated with insulin alone (regardless of whether or not cells were co-incubated with GO).

Our finding that GO-mediated oxidative stress inhibits insulin-mediated glucose uptake is in agreement with some $[10,21,26]$ but not all $[6,8,19,30]$ previous investigations. Discrepancies in the results of various studies can, in part, be explained by the differences in the experimental design, such as in vivo versus in vitro models and dose and duration of exposure to the compounds under investigation. Various levels of oxidative stress have been induced between 25 and $100 \mathrm{mU} / \mathrm{ml} \mathrm{GO}$ for periods varying between $5 \mathrm{~min}$ and $24 \mathrm{~h}$. In agreement with the results of previous studies $[10,26]$, we found that the induction of $\mathrm{H}_{2} \mathrm{O}_{2}$ via $100 \mathrm{mU} / \mathrm{ml} \mathrm{GO}$ for $1 \mathrm{~h}$ in $\mathrm{L} 6$ myotubes impaired insulin-stimulated glucose transport. Importantly, however, the lack of effect of GO on selected proteins in the insulin signaling cascade suggests oxidative stress impairs cellular insulinstimulated glucose transport via mechanism/s that are at least partly unrelated to these enzymes, at least under the current experimental conditions. Thus the precise mechanism by which ROS impairs glucose uptake remains to be determined. Nevertheless improved glucose uptake and insulin signaling by pretreatment with GT suggests that this antioxidant plays some role in counteracting effect of oxidative stress, and indeed potentially enhancing insulin signaling beyond insulin alone in certain circumstances.

The disconnect between glucose transport and insulin signaling (i.e. Akt and AS160 phosphorylation) in the current study strongly suggest that there are other mechanisms by which GT improved glucose

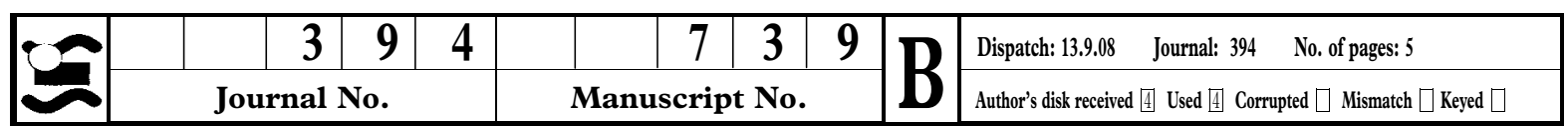


transport. Given that the pre-treatment with GT was more prolonged than the GO exposure, we speculate that reduced lipid peroxidation affords some improvement in cell membrane dynamics and interactions with transporters such as GLUT4, or some other local factor in the vicinity. The role of free radical attack in diabetes and in the cardiovascular complications of the disease has been documented largely through the effects of free radicals on lipids and proteins $[9,23,24]$. GT has been shown to act on the cell surface by preventing oxidation of LDL in cell membranes [15]. However, there is no evidence to suggest such mechanisms exist to prevent ROS-induced insulin resistance, and this is an area that requires further study.

The mechanism(s) by which $\mathrm{H}_{2} \mathrm{O}_{2}$ and other mediators of oxidative stress cause insulin resistance are largely unknown. A possible explanation for the inhibitory effect of $\mathrm{H}_{2} \mathrm{O}_{2}$ on insulin action is that it triggers an alteration in cellular redox balance due to prolonged exposure. Stress inducers, including $\mathrm{H}_{2} \mathrm{O}_{2}$, can function as signaling molecules to activate a number of stress sensitive serine/threonine kinase pathways linked to insulin resistance [5]. Insulin signaling enzymes offer a number of potential substrates for these activated serine kinases including the insulin receptor and the family of insulin receptor substrate proteins, which act to increase glucose transport through activating downstream enzymes such as Akt and AS160. Numerous agents that induce insulin resistance, such as TNF- $\alpha$, platelet-derived growth factor, angiotensin and hyperinsulinemia, all impair insulin signaling through induction of ROS $[22,29]$, which might explain their insulin de-sensitizing effects. In contrast, since we find that neither Akt nor AS160 phosphorylation were significantly impacted upon by GO treatment, the source of the ROS-induced impairment of insulin sensitivity lies, at least in part, elsewhere. Additional research that links the production of ROS and its removal by GT and other antioxidants, to impairment of insulin signaling events is clearly warranted to clarify this issue.

In conclusion, we found that acute oxidative stress impaired insulin-stimulated glucose transport in L6 myotubes, while pre-treatment with GT reversed this impairment. However, the disconnect between glucose uptake and the phosphorylation state of selected proteins in the insulin signaling cascade suggests that GT improves glucose transport via both insulindependent and independent mechanisms. Our results suggest that dietary supplementation with GT may play a preventive role in counteracting effect of oxidative stress on glucose uptake by skeletal muscle cells. In addition, identification of the molecular basis for this observation might lead to the discovery of pharmacological targets for novel therapies to prevent, reverse or delay the onset of insulin resistance and resultant pathogenesis.

Acknowledgments A.L.C. is supported by a Peter Doherty PostDoctoral Fellowship from the National Health and Medical Research Council of Australia (NHMRC), M.A.F is a Principal Research Fellow of the NHMRC.

\section{References}

1. Chan AC (1998) Vitamin E and atherosclerosis. J Nutr 128:1593-1596

2. Defronzo RA, Gunnarsson R, Bjorkman O, Olsson M, Wahren J (1985) Affects of insulin on peripheral and splanchnic glucose metabolism in noninsulindependent (type II) diabetes mellitus. J Clin Invest 76:149-155

3. Devraj S, Leonard S, Traber MG, Jialal I (2008) Gamma-tocopherol supplementation alone and in combination with alpha-tocopherol alters biomarkers of oxidative stress and inflammation in subjects with metabolic syndrome. Free Radic Biol Med 44:1203-1208

4. Dokken BB, Saengsirisuwan V, Kim JS, Teachey MK, Henriksen EJ (2008) Oxidative stress-induced insulin resistance in rat skeletal muscle: role of glycogen synthase kinase-3. Am J Physiol Endocrinol Metab 294:E615E621
5. Evans JL, Goldfine ID, Maddaux BA, Grodsky GM (2003) Are oxidative stress-activated signaling pathways mediators of insulin resistance and beta-cell dysfunction? Diabetes Care 52:1-8

6. Evans JL, Maddux BA, Goldfine ID (2005) The molecular basis for oxidative stress-induced insulin resistance. Antioxid Redox Signal 7:1040-1052

7. Faure P, Rossini E, Lafond JL, Richard MJ, Favier A, Halimi S (1997) Vitamin $\mathrm{E}$ improves the free radical defense system potential and insulin sensitivity of rats fed high fructose diets. J Nutr 127:103-107

8. Fischer Y, Rose H, Thomas J, Deuticke B, Kammermeier H (1993) Phenylarsine oxide and hydrogen peroxide stimulate glucose transport via different pathways in isolated cardiac myocytes. Biochim Biophys Acta 1153:97104
9. Giugliano D, Ceriello A, Paolisso G (1996) Oxidative stress and diabetic vascular complications. Diabetes Care 19:257-267

10. Hansen LL, Ikeda Y, Olsen GS, Busch AK, Mostha L (1999) Insulin signaling is inhibited by micromolar concentrations of $\mathrm{H}_{2} \mathrm{O}_{2}$. J Biol Chem 274:2507825084

11. Hawley SA, Davison M, Woods A, Davies SP, Beri RK, Carling D, Hardie DG (1996) Characterization of the AMP-activated protein kinase kinase from rat liver and identification of threonine 172 as the major site at which it phosphorylates AMP-activated protein kinase. J Biol Chem 271:27879-27887

12. Hayashi T, Hirshman MF, Kurth EJ, Winder WW, Goodyear LJ (1998) Evidence for $5 \mathrm{k}$ AMP-activated protein kinase mediation of the effect of muscle contraction on glucose transport. Diabetes 47:1369-1373

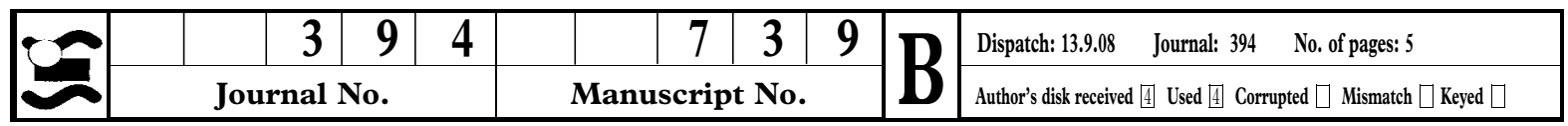


13. Hayes GR, Lockwood DH (1987) Role of insulin receptor phosphorylation in the insulinomimetic effects of hydrogen peroxide. Proc Natl Acad Sci 84:8115-8119

14. Heffetz D, Bushkin I, Dror R, Zick Y (1990) The insulinomimetic agents $\mathrm{H}_{2} \mathrm{O}_{2}$ and vanadate stimulate protein tyrosine phosphorylation in intact cells. J Biol Chem 265:2896-2902

15. Hodis HN, Mack WJ, Labree L, Mahrer $\mathrm{PR}$, Sevanian A, Liu CR, Liu $\mathrm{CH}$, Hwang J, Selzer RH, Azen SP (2002) Alpha-tocopherol supplementation in healthy individuals reduced low-density lipoprotein oxidation but not atherosclerosis: the Vitamin $\mathrm{E}$ Atherosclerosis Prevention Study (VEAPS). Circulation 106:1453-1459

16. Houseknecht KL, Kahn BB (1997) Molecular mechanisms for insulinstimulated glucose transport: regulation of Glut4 translocation. J Anim Sci 75:32-45

17. Houstis N, Rosen ED, Lander ES (2006) Reactive oxygen species have a causal role in multiple forms of insulin resistance. Nature 440:944-948

18. JeBailey L, Wanono O, Niu W, Roessler J, Rudich A, Klip A (2007) Ceramideand oxidant-induced insulin resistance involve loss of insulin-dependent Racactivation and actin remodeling in muscle cells. Diabetes 56:394-403

19. Kozlovsky N, Rudich A, Potashnik A, Bashan N (1997) Reactive oxygen species activate glucose transport in L6 myotubes. Free Radic Biol Med 23:859869
20. Liu M, Wallmon A, Olsson-Mortlock C, Wallin R, Saldeen T (2003) Mixed tocopherols inhibit platelet aggregation in humans: potential mechanisms. Am J Clin Nutr 77:700-706

21. Maddux BA, See W, Lawrence JC Jr, Goldfine AL, Goldfine AD, Evans JL (2001) Protection against oxidative stress-induced insulin resistance in rat L6 muscle cells by mircomolar concentrations of alpha-lipoic acid. Diabetes 50:404-410

22. Nishikawa T, Kukidome D, Sonoda K, Fujisawa K, Matsuhisa T, Motoshima H, Matsumura T, Araki E (2007) Impact of mitochondrial ROS production in the pathogenesis of insulin resistance. Diabetes Res Clin Pract 77:S161S164

23. Oberley LW (1988) Free radicals and diabetes. Free Radic Biol Med 5:113124

24. Ozdemirler G, Mehmetcik G, Oztezcan S, Toker G, Sivas A, Uysal M (1995) Peroxidation potential and antioxidant activity of serum in patients with diabetes mellitus and myocardial infarction. Horm Metab Res 27:194-196

25. Rosen P, Nawroth P, King GL, Moller W, Tritschler HJ, Packer L (2001) The role of oxidative stress in the onset and progression of diabetes and its complications: a summary of a Congress Series sponsored by UNESCO-MCBN, the American Diabetes Association and the German Diabetes Society. Diabetes Metab Res Rev 17:189-212

26. Rudich A, Kozlovsky N, Potashnik R, Bashan N (1997) Oxidant stress reduces insulin responsiveness in 3T3-L1 adipocytes. Am J Physiol 272:E935E940
27. Rudich A, Tiroshi A, Potashnik R, Hemi R, Kanety H, Bashan N (1998) Prolonged oxidative stress impairs insulin-induced GLUT4 translocation in 3T3-L1 adipocytes. Diabetes 47:1562-1569

28. Singh I, Turner AH, Sinclair AJ, Li D, Hawley JA (2007) Effects of gammatocopherol supplementation on thrombotic risk factors. Asia Pac J Clin Nutr 16:422-428

29. Sykiotis GP, Papavassiou AG (2001) Serine phosphorylation of insulin receptor substrate-1: a novel target for the reversal of insulin resistance. Mol Endocrinol 15:1864-1869

30. Timar L, Czeizel AE, Kozlovsky N, Rudich A, Potashnik A, Bashan N (1997) Reactive oxygen species activate glucose transport in L6 myotubes. Free Radic Biol Med 23:859-869

31. Tirosh A, Potashnik R, Bashan N, Rudich A (1999) Oxidative stress disrupts insulin-induced cellular redistribution of insulin receptor substrate-1 and phosphatidylinositol 3-kinase in 3T3-L1 adipocytes: a putative cellular mechanism for impaired protein kinase B activation and GLUT4 translocation. J Biol Chem 274:10595-10602

32. West IC (2000) Radicals and oxidative stress in diabetes. Diabetic Med 17:171-180

33. Wolf G (1997) Tocopherol: an efficient protector of lipids against nitric oxideinitiated peroxidative damage. Nutr Rev 55:376-378 